\title{
Dendrimers as anti-inflammatory agents
}

\author{
Pramod K. Avti ${ }^{1,2,3}$, Ashok Kakkar ${ }^{3, *}$
}

${ }^{1}$ Montreal Heart Institute, Research Center, Montréal, Canada, ${ }^{2}$ Institute of Biomedical Engineering, École Polytechnique de Montréal, Montreal, Canada, ${ }^{3}$ Department of Chemistry, Faculty of Science, McGill University, Montreal, Canada

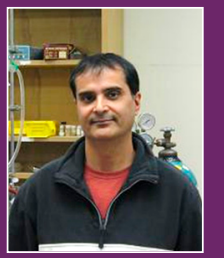

Ashok Kakkar is an Associate Professo in the Department of Chemistry at McGil University, Montreal, Quebec, Canada. His research interests include developing methodologies to complex architectures (hyperbranched macromolecules including dendrimers, miktoarm polymers, metal nanoparticles), and studying their efficacy in biological processes including drug delivery and theranostics.

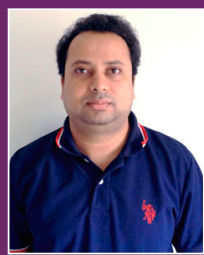

Pramod Avti is a Postdoctoral Fellow at Montreal Heart Institute, Montreal, Quebec, Canada working on a collaborative project with Department of Chemistry, McGill University and Ecole Polytechnique, Montreal Canada. His current scientific interests include multifunctional nanomaterials synthesis, mut their biomedical applications. and their biomedical applications. I particular, his research is aimed at synthesis, interaction and conjugation of drug or gene-dendrimer conjugates to the gold nanoshells for biomedical imaging and as theranostic agents.
*Correspondence: Ashok Kakkar. Department of Chemistry, 801 Sherbrooke St. West, McGill University, Montreal, QC H3A 0B8, Canada. E- mail: ashok.kakkar@mcgill.ca
Dendrimers constitute an intriguing class of macromolecules which find applications in a variety of areas including biology. These hyperbranched macromolecules with tailored backbone and surface groups have been extensively investigated as nanocarriers for gene and drug delivery, by molecular encapsulation or covalent conjugation. Dendrimers have provided an excellent platform to develop multivalent and multifunctional nanoconjugates incorporating a variety of functional groups including drugs which are known to be antiinflammatory agents. Recently, dendrimers have been shown to possess anti-inflammatory properties themselves. This unexpected and intriguing discovery has provided an additional impetus in designing novel active pharmaceutical agents. In this review, we highlight some of the recent developments in the field of dendrimers as nanoscale anti-inflammatory agents.

Uniterms: Dendrimers. Nanocarriers. Anti-inflammatory agents. Cyclooxygenase (COX-2). Inducible nitric oxide synthase (iNOS). Pro-inflammatory cytokines.

Dendrímeros constituem uma classe intrigante de macromoléculas que apresentam aplicações em diversas áreas incluindo biologia. Essas macromoléculas extremamente ramificadas com esqueleto planejado e grupos de superfície foram extensivamente investigadas como nanotransportadores de genes e de fármacos, por encapsulamento molecular ou conjugação covalente. Dendrímeros têm proporcionado uma plataforma excelente de desenvolvimento nanoconjugados multivalentes e multifuncionais incorporando uma variedade de grupos funcionais, incluindo fármacos que são conhecidos por atuarem agentes antiinflamatórios. Recentemente, os dendrímeros mostraram propriedades antiinflamatórias. Esta inesperada e intrigante descoberta tem proporcionado um impulso adicional no planejamento de novos agente farmacêuticos ativos. Nesta revisão, nós destacamos alguns dos desenvolvimentos recentes no campo dos dendrímeros como agentes antiinflamatórios em nanoescala.

Unitermos: Dendrímeros. Nanotransportadores. Agentes antiinflamatórios. Ciclooxigenase (COX-2). Óxido nítrico sintase induzível (iNOS). Citocinas pró-inflamatórias.

\section{INTRODUCTION}

The term dendrimer is derived from a Greek word dendron which means tree, and reflects their structure. Though this terminology was coined in the mid 1980's by Tomalia, the first synthesis of dendrimers is credited to Vogtle and co-workers in 1978 (Buhleier et al., 1978). Dendrimers are synthetic macromolecules with well-defined shapes, and possess three main components: central core, repeating branch units and the dense shell with terminal functional groups. These distinct macromolecules depict unique physicochemical properties that are different than traditional linear 
and branched polymers. This is due to the step-by-step controlled growth, in contrast to direct polymerization in well studied linear polymers, and employs small organic molecules as structural components to obtain monodispersity (Tomalia et al., 1990; Frechet, Tomalia, 2002; Svenson, Tomalia, 2005; Tomalia, 2005). The overall size, shape, molecular weight, density, polarity, flexibility and solubility of dendrimers are well controlled and depend on the choice of the structural components, central core, the branching units and the terminal functional groups used. Unlike other polymeric structures (Hadjichristidis, 2000; Schluter, Rabe, 2000; Hult, 2003; Haag, Kratz, 2006), dendrimers are easy to reproduce structurally. This has led to tremendous potential in their applications as drug delivery agents. Dendrimers can render water solubility, bioavailability and biocompatibility to active pharmaceutical agents. Over the years dendrimers have been developed based on their multivalent structure and supramolecular properties as attractive nanocarriers for applications in pharmaceutical and biomedical sciences (Sharma et al., $2011 \mathrm{a}, \mathrm{b})$. It is no surprise then that much attention has been directed towards their ability as nanocontainers for a variety of drug molecules including anti-inflammatory agents (Milhem et al., 2000; Kolhe et al., 2003; Chauhan et al., 2004; Sharma et al., 2011a; Soliman et al., 2011). Milhem and Kolhe groups have shown that a G4 PAMAM dendrimer can contain approximately 41 and 78 ibuprofen (a non-steroidal anti-inflammatory drug) molecules, either by way of encapsulation into the interior cavities by hydrophobic interactions or attached to the surface by electrostatic interactions (Milhem et al., 2000; Kolhe et al., 2003). Chauhan and his colleagues have shown the encapsulation of indomethacin into PAMAM dendrimers to improve the in vivo distribution by $\sim 2.3$ times at the inflamed regions as compared to the free drug (Chauhan et al., 2004). Other groups have reported the effect of dendrimer concentration, generation and $\mathrm{pH}$ effects on the solubilization of drugs (Wiwattanapatapee et al., 1999; Cheng et al., 2005). These studies have shown that increasing the generation number of the dendrimer at higher $\mathrm{pH}$ increases drug solubility, and the presence of amine terminal groups would improve the electrostatic interactions of the drug with carboxyl end groups. More recently there have been reports suggesting that dendrimers themselves can act as anti-inflammatory agents. In this review, progress towards an evaluation of the anti-inflammatory properties of the dendrimers, are discussed.

\section{Synthesis of dendrimers}

The two commonly used synthetic strategies for dendrimers include divergent and the convergent methods (Buhleier et al., 1978; Tomalia et al., 1984; Newkome et al., 1985; Tomalia et al., 1985; Hawker, Frechet, 1990; Hourani, Kakkar, 2010). The divergent method uses bottom-up approach where the synthesis of dendrimer is carried out beginning at the central core and moves towards the surface (Figure 1). The branched building units react with the core, and subsequently their terminal groups are activated which in turn react with the other branched building units. The purification process at each reaction step helps obtain uniform structure and specific molecular weight. The repetition of these reaction cycles, called as generations $(G)$, grows the macromolecule outwards. The molecular weight and number of terminal groups are determined by the dendrimer generation. The number of terminal groups $(Z)$ could be calculated using a mathematical equation $\mathrm{Z}=$ $\mathrm{N}_{\mathrm{c}} \mathrm{N}_{\mathrm{b}} \mathrm{G}$ where $\mathrm{N}_{\mathrm{c}}, \mathrm{N}_{\mathrm{b}}, \mathrm{G}$ are the core multiplicity, branch cell multiplicity and generation number respectively (Frechet, Tomalia, 2001; Tomalia, 2005). Some of the commercially available dendrimers like polyamidoamine (PAMAM), polypropyleneimine (PPI) are prepared by the divergent synthetic method.

The convergent method developed by Frechet, uses top-down approach in which the synthesis starts from the periphery and ends towards the central core (Freeman et al., 1997). In this method, a branched dendron is first prepared, and then reacted with the central core to form the final dendrimer (Figure 1). The synthesis of poly(aryl ether) dendrimers is one common example of this method (Grayson, Frechet, 2001). The advantages of convergent methodology include easy purification of the desired product, defect minimized final product, easy and precise placement of peripheral functional groups.

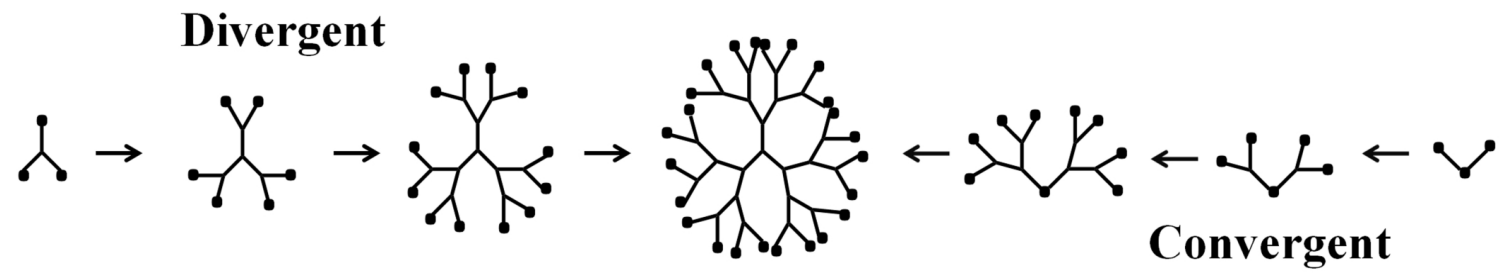

FIGURE 1 - Schematic showing the divergent versus convergent synthetic strategies. 


\section{Conformational changes}

Low generation dendrimers $(0,1$ and 2$)$ possess asymmetric shape and open structure and become globular as higher generations are achieved. As the dendrimer grows, it becomes densely packed and extends out to the periphery, and due to steric hindrance further elongation or branching stops (Fischer, Vogtle, 1999). With increase in each generation, the branch density increases leading to the formation of internal cavities and a large number of terminal end groups.

\section{Physicochemical properties}

Some of the important physicochemical properties of dendrimers originate from their overall conformation, and their cascade architecture provides unique properties for applications in the biomedical field. Dendrimers in solution possess rheological properties as they form closely packed ball like structures. The terminal end groups of the dendrimers render them high solubility, miscibility and high reactivity (Frechet, 1994).

\section{Dendrimers as anti-inflammatory agents}

In this section, we summarize not only the antiinflammatory role of dendrimers displayed towards immune cells derived from myeloid lineage (such as monocyte-derived macrophages (MDMs), and immature dendritic cells) (Shaunak et al., 2004), peripheral blood monocytes (Fruchon et al., 2009) and peritoneal macrophages (Chauhan et al., 2009), but also towards the extravasation of inflammatory effectors (leukocytes) at the site of inflammation (Ulbrich et al., 2003), anti-HIV activity, anti-arthritis effect and inhibition of iNOS and COX-2 enzymes etc.

\section{Proinflammatory cytokines}

Recently, dendrimers without any drug encapsulated or covalently bound have shown therapeutic potential as anti-inflammatory agents. This is mainly due to the immunomodulatory alterations in pathophysiological response of the immune system. The first ever report on the anti-inflammatory properties of dendrimers was studied as a preventive agent in scar tissue formation. Here, 1,2-diaminoethane-cored generation 4.5 poly(amidoamine) (PAMAM) skeleton with 64 carboxylic acid surface groups was used. Of the 64 carboxylic groups, nine had been amido-conjugated to glucosamine and glucosamine6-sulfate (Shaunak et al., 2004). The dendrimer glucosamine inhibited the release of proinflammatory chemokines (macrophage inhibitory protein [MIP]-1 $\alpha$ and $-1 \beta$, interleukin [IL]-8) and cytokines (tumor necrosis factor [TNF]- $\alpha$, IL- $1 \beta$ and IL-6) in the the lipopolysaccharide (LPS)-stimulated immune cells such as monocyte-derived macrophages (MDMs) and immature monocyte-derived dendritic cells (DCs) (Shaunak et al., 2004). On the other hand, dendrimer with nine 6-O-sulfated glucosamine residues (DGS) showed no inflammatory effect, but rather displayed anti-angiogenic properties.

\section{Immune cellular response}

PAMAM dendrimers are the most commonly studied for anti-inflammatory properties. In a recent study, PAMAM dendrimers with terminal- $\mathrm{NH}_{2}\left(\mathrm{G} 4-\mathrm{NH}_{2}\right)$, $-\mathrm{OH}(\mathrm{G} 4-\mathrm{OH})$ and $-\mathrm{COOH}\left(\mathrm{G} 4.5-\mathrm{CO}_{2} \mathrm{H}\right)(\mathrm{Chauhan}$ et al., 2009) were used for the in vitro analysis of LPS-induced nitric oxide (NO) and cyclo-oxygenase 2 (COX-2) activity in rat peritoneal macrophages. $\mathrm{G}_{4}-\mathrm{NH}_{2}$ and $\mathrm{G} 4-\mathrm{OH}$ dendrimers showed maximum inhibitory activity as compared to G4.5- $\mathrm{CO}_{2} \mathrm{H}$. In another study, the aminoethylethanolamine-capped dendrimers (G4-AEEA) and hydroxyl terminated dendrimers $(\mathrm{G} 4-\mathrm{OH})$ displayed highest inhibitory activity of COX-2. Other dendrimers terminated with tris(hydroxymethyl)aminomethane (G4-Tris), N-(3carbomethoxy) pyrrolidone (G4-Pyr), or polyethylene glycol (G4-PEG) groups showed decreasing inhibitory effects. Carboxylated and succinamic acid -capped (G4$\mathrm{CO}_{2} \mathrm{H}$ and $\mathrm{G} 4-\mathrm{SUC}$ ) dendrimers had no effect on COX-2 inhibition.

Recent studies have shown that azabisphosphonate (capped by amino-bisphosphonate groups) (ABP) dendrimers treatment changes the human monocytes $(\mathrm{V} \gamma 9 \mathrm{~V} \delta 2$ T lymphocytes) phenotype with an increase in their phagocytic activity (Espinosa et al., 2001; Poupot et al., 2006). ABPs have also shown to have immunomodulatory effects and promote natural killer (NK) cells proliferation in cultures of peripheral blood mononuclear cells (PBMCs). The NK cells act as cytotoxic effectors against virus, bacteria or parasite-infected cells and also inhibit the proliferation of CD4+ T lymphocytes (Griffe et al., 2007; Portvein et al., 2009). ABPs at the gene and protein levels have shown increased expression of anti-inflammatory products like mannose receptor MRC1 with reduced levels of CD64 and CD13 (Fruchon et al., 2009). Therefore, it is clear that $\mathrm{ABP}$ has anti-inflammatory and immunomodulatory effects in vitro either directly on monocytes or indirectly on other immune cells, and has shown some similarities with the glucocorticoid properties as immunosuppressive drugs (Ehrchen et al., 2007).

\section{Cell adhesion molecules}

Recently, Rele's group synthesized 3- and 4-arm 
PEO 'stars' and second generation dendrimer on the $\mathrm{N}_{3} \mathrm{P}_{3}$ core, which showed comparable anti-inflammatory properties to that of heparin (sulfated polysaccharide) (Rele et al., 2005). These dendrimers have terminal hydroxylated lactose end groups in which the hydroxyls groups are free, acetylated or sulfated. They exhibited anti-inflammatory properties by blocking P-and L-selectins via sulfate-dependent interactions. When the PEO stars and sulfated PEOs were injected $(20 \mathrm{mg} / \mathrm{kg}$ b.wt) into mice models of acute inflammation, generated by intraperitoneal injection of thioglycollate, it drastically reduced the infiltration of neutrophils and macrophages. It was concluded that this inhibition is brought about by the selectins. This was confirmed in vitro, where dendrimer inhibited the U937 lymphoma cell adhesion to immobilized P- and L-selection without any effect on E-selectin similar to that of heparin. It is because of the absence of positively charged motifs in the binding pockets of E-selectin as compared to P- and L-selectin. Similarly, Dernedde and his colleagues synthesized polyglycerol sulfates (dPGS) as heparin analogs with different core size $(2.5$ and $6 \mathrm{kDa})$ and degree of sulfation $(0-61$ [dPG $\left.-\mathrm{dPGS}_{61}\right]$ ) (Dernedde et al., 2010). dPGS ${ }_{61}$ showed high anti-inflammatory properties in the acute allergic contact dermatitis mice model (ear swelling, redness, edema and cellular infiltration) by targeting both L-selectin on leukocytes and P-selectin on endothelial cells and inhibiting the generation of anaphylatoxin $\mathrm{C} 5 \mathrm{a}$ (causes enhanced vascular permeabilization).

\section{Anti-viral activity}

In a recent study, sulfated and non-sulfated sialic acidPAMAM glycodendrimers were synthesized to assess the anti-HIV-1 properties (Clayton et al., 2011). The divergent method proved more effective than the convergent one in the synthesis of generation 0,1 and 2 sialic acidPAMAM conjugates. The sulfo- 6 , a generation 2 sulfated sialic acid-PAMAM glycodendrimer having 16 sialic acids and 11 sulfate groups had the highest inhibitory activity in the micromolar range on all the tested HIV-1 strains [Q23.17 (Clade A), MN.3 (Clade B), MW965.26 (Clade C), and TV1.21 (Clade C)]. In an earlier study, sulfated galactosylceramide(SGalCer)-coated polypropyleneimine (PPI) dendrimers showed binding affinity towards HIV protein, gp120, in the nanomolar (nM) range as compared to picomolar (pM) affinity of dextran sulfate, a known HIV inhibitor. These dendrimers have also prevented infection in CD4-negative cells (Kensinger et al., 2004a; 2004b). Other types of GalCer-based dendrimers having polyglycerol (PG) core (Morales-Serna et al., 2010) and phosphonic acid (PA) core (Perez-Anes et al.,
2010) were studied, and shown to inhibit cell-based HIV assays. However, one difference between the GalCer-PG, GalCer-PA and GalCer-PPI based dendrimers is that the earlier two dendrimer types have high cytotoxic effects as compared to the latter, though they have binding affinities in the sub micromolar $(\mu \mathrm{M})$ range (Blanzat et al., 2005; Perez-Anes et al., 2010). The other types of PPI core based dendrimers include terminating glycosphingolipid derived sugar head groups, 3'-siallyactose $\left(\mathrm{GM}_{3}\right)$ or globotriose $\left(\mathrm{Gb}_{3}\right)$ (Borges et al., 2010). Both these dendrimers showed anti-HIV-I activity in T-cells and primary peripheral blood mononuclear cells (PBMCs) in the sub $\mu \mathrm{M}$ range (Borges et al., 2010).

In another recent study, the generation one [G1]gallic acid-triethylene glycol (GATG) dendrimer was shown to inhibit the oligomerization of the HIV-1 capsid protein (CA) (Domenech et al., 2010). Oligomerization of immuature HIV-1 capsid is essential for the morphogenesis for its virulence and infection in the host CD4 cells. The C-terminal domain (CTD) of the CA is involved in the formation of hexamers which later join to form a homodimer. These dendrimers have shown to dissociate the homodimers of CTD $\left(K_{d} \sim 10 \mu \mathrm{M}\right)$ similar to designed peptide inhibitors weakening the dimerization process (Garzon et al., 2004; Stitch et al., 2005; Neira, 2009). In another study, the second (SPL7115) and fourth generation (SPL7013) dendrimers comprising benzyhydryl amide cores and lysine branches have shown anti-HIV activity by blocking HIV-envelope mediated cell-to-cell fusion (Rupp et al., 2007; Tyssen et al., 2010). SPL7115 and SPL7013 also inhibited the viral entry, through different mechanism of action, by showing high potency against CXCR4-(X4) and CCR5-using (R5) HIV-1 strains (Telwatte et al., 2011). SPL7013 dendrimer, a topical microbicidal agent in the clinical developments, is an active pharmacological constituent of VivaGel®.

\section{Rheumatoid Arthritis}

Rheumatoid arthritis (RA) is a chronic systemic inflammatory disorder of many tissues and organs mainly around the flexible joint regions. The proinflammatory cytokines IL-1 $\beta$, IL-17 and TNF- $\alpha$ produced by monocytes (T helper cells) and macrophage colony-stimulating factor (M-CSF) produced by macrophages are involved in the production of mature osteoclasts (osteoclastogenesis) through the receptor activator of nuclear factor- $\kappa \mathrm{B}$ ligand (RNAKL). These osteoclasts are responsible for bone resorption, a typical bone erosion mechanism involved in RA (Takayanagi, 2007). Recently, Hayder et al. (2011) explored the potential of dendrimers in arthritic mice models. They treated dendrimers capped with anionic 
azabisphophonate (ABP) end groups, dendrimer azamonophosphate (AMP) and polypropyleneimine (PPI), at a dose of $10 \mathrm{mg} / \mathrm{kg}$ four times weekly (figure 2A,B,C). Only ABP significantly inhibited the proinflammatory cytokines secretion and osteoclastogenesis process (Hayder et al., 2011) (Figure 2D).

\section{Arachidonic acid}

The steroidal and non-steroidal anti-inflammatory drugs (NSAIDs) provide one of the main classes of antiinflammatory therapy that mainly inhibit the arachidonic acid and prostaglandin synthesis pathways. Recently, Tomalia and his group suggested that dendrimers themselves can exhibit anti-inflammatory properties mainly through inhibiting COX-2 activity (Chauhan et al., 2009). Kakkar's group recently showed that dendrimers synthe-

A
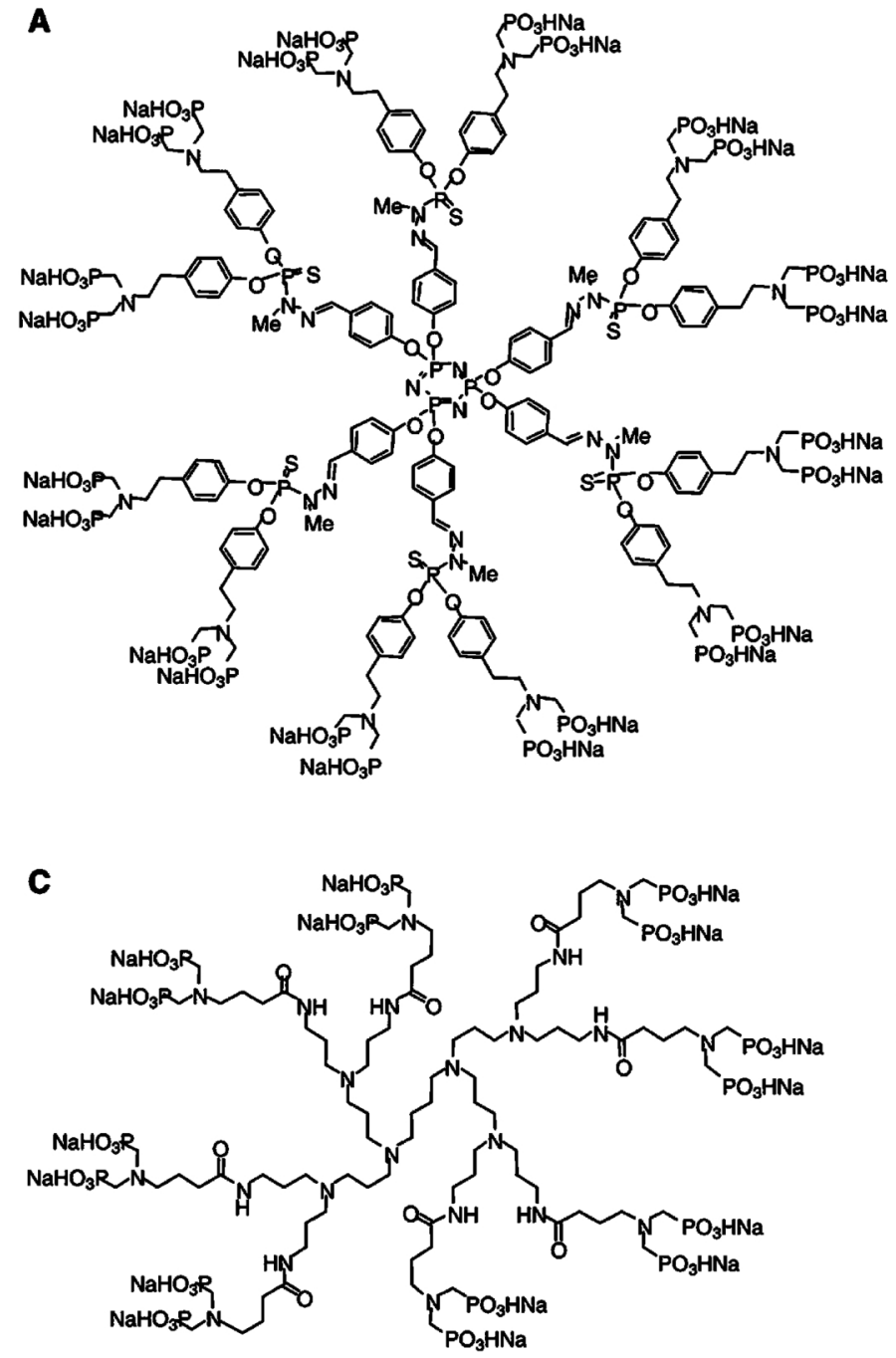

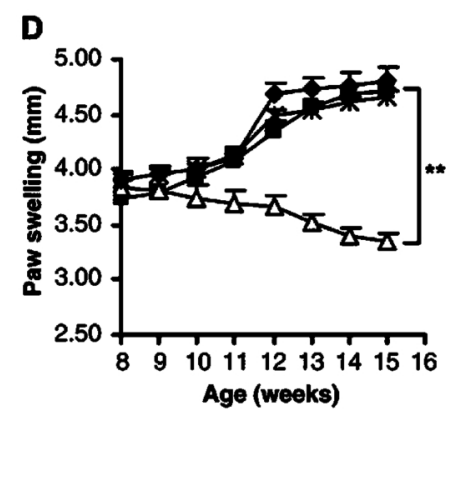

sized using alkyne-azide "click" chemistry act as antiinflammatory agents (Castonguay et al., 2011; Hourani, Kakkar et al., 2010; Sharma et al., 2011a,b). Dendrimers with terminated acetylene (A) (DG0-A, DG1-A and DG2A) and hydroxyl groups $(\mathrm{OH})(\mathrm{DG} 1-\mathrm{OH})($ Hourani et al., 2010) have shown to inhibit the LPS-induced nitric oxide (NO) and COX-2 (involved in prostaglandin (PGE2) synthesis in N9 microglia cells (resident immune cells of central nervous system). Treatment with DG1-OH showed the highest inhibitory activity of iNOS and COX-2 as compared to selective (Celecoxib) and non-selective (Ibuprofen) anti-inflammatory agents. Further, computational studies showed that these dendrimers bring about the antiinflammatory effect by direct binding to the active site of the enzymes iNOS and COX-2 (Niebert et al., 2013), an emerging anti-inflammatory mechanism of dendrimers.
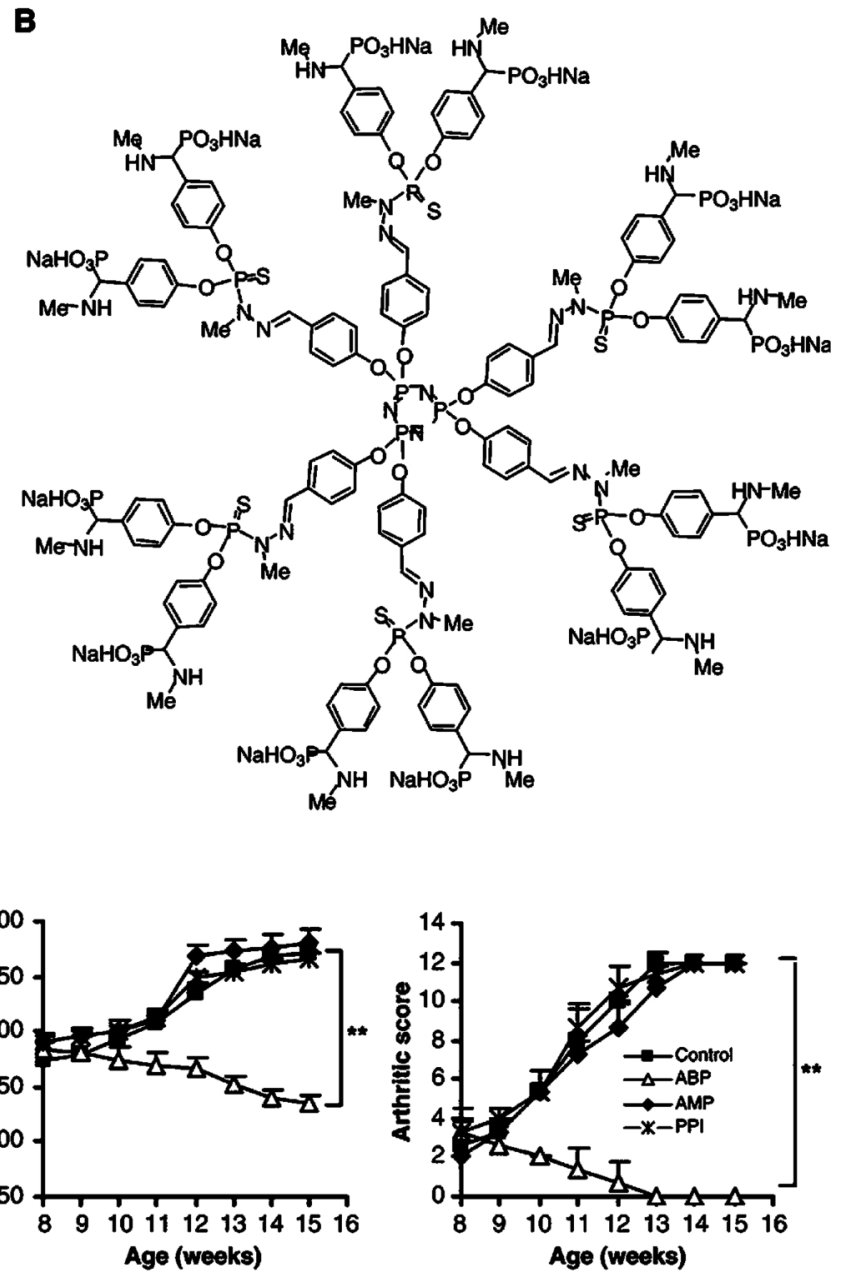

FIGURE 2 - Structure of dendrimers ABP (A), AMP (B) and PPI (C) used in IL-1ra -/- arthritis mice model studied by Hayder et al. (D) represent the comparative data of the effect of dendrimers ABP, AMP or PPI treated at a dose of $10 \mathrm{mg} / \mathrm{kg}$ on the development of external signs of arthritis (paw swelling and arthritic score) (Reprinted with permission from ACS Nano 2011, 5(9), 6779-6785. Copyright 2011 American Chemical Society). 


\section{CONCLUSIONS}

The unique properties of dendrimers have led to the development of a variety of applications of these macromolecules, including delivery of anti-inflammatory drugs. Inflammation is a complex network of events, and current therapies have not achieved much success in the treatment of inflammatory diseases as they either target a specific cytokine, receptor or a single cell. Recent investigations suggest that dendrimers themselves can act as anti-inflammatory agents. Dendrimers such as PAMAM terminated with carboxylic groups conjugated to glucosamine and related derivatives not only inhibit the release of cytokines but also affect the cellular phenotypes and functions (Shaunak et al., 2004). Azabisphophonate-based dendrimers showed phenotypic changes in phagocytic activity of human monocytes (Espinosa et al., 2001; Poupot et al., 2006). Some of the dendrimers with terminal hydroxylted lactose end groups, such as PEO, blocked the binding efficacy of cell adhesion molecules (Rele et al., 2005; Dernedde et al., 2010). While other dendrimers such as PPI and PAMAM with terminal sulfated galactosylceramide and sialic acid groups have direct binding affinity with the HIV proteins, involved in HIV infections (Clayton et al., 2011; Kensinger et al., 2004a; 2004b) and others affecting the CD4 cells (Borges et al., 2010; Perez-Anes et al., 2010). Dendrimers such as PAMAM with terminal $-\mathrm{NH}_{2},-\mathrm{OH}$ and $-\mathrm{COOH}$ groups have shown to inhibit iNOS and COX-2 (Chauhan et al., 2009). These diverse studies showing the anti-inflammatory properties of dendrimers point towards the role of terminal end groups, overall charge and the generation number in their activity. Though it is too early to comment on the structure-activity relationships of dendrimers and their anti-inflammatory behavior, but it is clear that these dendrimers show great promise in future as potential anti-inflammatory therapeutic agents.

\section{ACKNOWLEDGEMENTS}

We would like to thank the Natural Sciences and Engineering Research Council of Canada (NSERC) and Fonds de Recherche Nature et Technologie Québec (FQRNT) for financial support.

\section{REFERENCES}

ADRONOV, A.; GILAT, S.L.; FRÉCHET, J.M.J.; OHTA, K.; NEUWAHL, F.V.R.; FLEMING, G.R. Light harvesting and energy transfer in laser-dye-labeled poly(aryl ether) dendrimers. J. Am. Chem. Soc., v.122, p.1175-1185, 2000.
ARCHUT, A.; AZZELLINI, G.C.; BALZANI, V.; COLA, L.D.; VÖGTLE, F. Toward photoswitchable dendritic hosts. Interaction between azobenzene-functionalized dendrimers and eosin. J. Am. Chem. Soc., v.120, p.12187-12191, 1998.

BLANZAT, M.; TURRIN, C.-O.; AUBERTIN, A.-M.; COUTURIER-VIDA, C.; CAMINADE, A.-M.; MAJORAL, J.-P.; RICO-LATTES, I.; LATTES, A. Dendritic catanionic assemblies: in vitro anti-HIV activity of phosphorous-containing dendrimers bearing Gal $\beta 1 \mathrm{Cer}$ analogs. Chem. Biol. Chem., v.6, p.2207-2213, 2005.

BORGES, A.R.; WIECZOREK, L.; JOHNSON, B.; BENESI, A.J.; BROWN,B.K.; KENSINGER, R.D.; KREBS, F.C.; WIGDAHL, B.; BLUMENTHAL, R.; PURI, A.;MCCUTCHAN, F.E.; BIRX, D.L.; POLONIS, V.R.; SCHENGRUND, C.-L. Multivalent dendrimeric compounds containing carbohydrates expressed on immune cells inhibit infection by primary isolates of HIV-1. Virology, v.408, p.80-88, 2010.

BUHLEIER, E.; WEHNER, W.; VÖGTLE, F. Cascadeand Nonskid-Chain-like syntheses of molecular cavity topologies. Synthesis, v.2, p.155-158, 1978.

CASTONGUAY, A.; WILSON, E.; AL-HAJAJ, N.; PETITEJEAN, L.; PAOLETTI, J.; MAYSINGER, D.; KAKKAR, A. Thermosensitive dendrimer formulation for drug delivery at physiologically relevant temperatures. Chem. Commun., v.47, p.12146-12148, 2011.

CHAUHAN, A.S.; DIWAN, P.V.; JAIN, N.K.; TOMALIA, D.A. Unexpected in vivo anti-inflammatory activity observed for simple, surface functionalized poly(amidoamine) dendrimers. Biomacromolecules, v.10, p.1195-1202, 2009.

CHAUHAN, A.S.; JAIN, N.K.; DIWAN, P.V.; KHOPADE, A.J. Solubility enhancement of indomethacin with poly(amidoamine) dendrimers and targeting to inflammatory regions of arthritic rats. J. Drug Targeting, v.12, p.575-583, 2004.

CHENG, Y.Y.; XU, T.W. Dendrimers as potential drug carriers. Part I. solubilization of non-steroidal anti-inflammatory drugs in the presence of polyamidoamine dendrimers. Eur. J. Med. Chem., v.40, p.1188-1192, 2005.

CLAYTON, R.; HARDMAN, J.; LABRANCHE, C.C.; MCREYNOLDS, K.D. Evaluation of the synthesis of sialic acid-PAMAM glycodendrimers without the use of sugar protecting groups, and the anti-HIV-1 properties of these compounds. Bioconjugate Chem., v.22, p.2186-2197, 2011. 
DERNEDDE, J.; RAUSCH, A.; WEINHART, M.; ENDERS, S.; TAUBER, R.; LICHA, K.; SCHIRNER, M.; ZÜGEL, U.; VON BONIN, A.; HAAG, R. Dendritic polyglycerol sulfates as multivalent inhibitors of inflammation. Proc. Natl. Acad. Sci. U.S.A., v.107, p.19679-19684, 2010.

DOMÉNECH, R.; ABIAN, O.; BOCANEGRA, R.; CORREA, J.; SOUSA-HERVES, A.; RIGUERA, R.; MATEU,M.G.; FERNANDEZ-MEGIA, E.; VELÁZQUEZ-CAMPOY, A.; NEIRA, J.L. Dendrimers as potential inhibitors of the dimerization of the capsid protein of HIV-1. Biomacromolecules, v.11, p.2069-2078, 2010.

EHRCHEN, J.; STEINMÜLLER, L.; BARCZYK, K.; TENBROCK, K.; NACKEN, W.; EISENACHER, M.; NORDHUES, U.; SORG, C.; SUNDERKÖTTER, C.; ROTH, J. Glucocorticoids induce differentiation of a specifically activated, anti-inflammatory subtype of human monocytes. Blood, v.109, p.1265-1274, 2007.

ESPINOSA, E.; BELMANT, C.; SICARD, H.; POUPOT, R.; BONNEVILLE, M.; FOURNIÉ, J.J. Y2K+1 state-ofthe-art or non-peptide phosphoantigens, a novel category of immunostimulatory molecules. Microbes Infect., v.3, p.645-654 2001

FISCHER, M.; VÖGTLE, F. Dendrimers: from design to applications - a progress report. Angew. Chem. Int. Ed., v.38, p.884-905, 1999.

FRÉCHET, J.M.J. Functional polymers and dendrimers: reactivity, molecular architecture, and interfacial energy. Science, v.263, p.1710-1715, 1994.

FRUCHON, S.; POUPOT, M.; MARTINET, L.; TURRIN, C.O.; MAJORAL, J.P.; FOURNIÉ, J.J.; CAMINADE, A.M.; POUPOT, R. Anti-inflammatory and immunosuppressive activation of human monocytes by a bio-active dendrimer. J. Leukocyte Biol., v.85, p.553-562, 2009.

GARZÓN, M.T.; LIDÓN-MOYA, M.C.; BARRERA, F.N.; PRIETO, A.; GÓMEZ, J.; MATEU, M.G.; NEIRA, J.L. The dimerization domain of the HIV-1 capsid protein binds a capsid protein-derived peptide: a biophysical characterization. Protein Sci., v.13, p.1512-1523, 2004.

GILAT, S.L.; ADRONOV, A.; FRÉCHET, J.M.J. Light harvesting and energy transfer in novel convergently constructed dendrimers. Angew. Chem. Int. Ed., v.38, p.1422-1427, 1999.
GRIFFE, L.; POUPOT, M.; MARCHAND, P.; MARAVAL, A.; TURRIN, C.O.; ROLLAND, O.; MÉTIVIER, P.; BACQUET, G.; FOURNIÉ, J.J.; CAMINADE, A.M.; POUPOT, R.; MAJORAL, J.P. Multiplication of human natural killer cells by nanosized phosphonate-capped dendrimers. Angew. Chem. (Int. Ed. Engl.), v.46, p.25232526, 2007.

HAWKER, C.J.; FRECHET, J.M.J. Preparation of polymers with controlled molecular architecture-a new convergent approach to dendritic macromolecules. J. Am. Chem. Soc., v.112, p.7638-7647, 1990.

HAYDER, M.; POUPOT, M.; BARON, M.; NIGON, D.; TURRIN, C.O.; CAMINADE, A.M.; MAJORAL, J.P.; EISENBERG, R.A.; FOURNIÉ, J.J.; CANTAGREL, A.; POUPOT, R.; DAVIGNON, J.L. A phosphorus-based dendrimer targets inflammation and osteoclastogenesis in experimental arthritis. Sci. Transl. Med., v.3, p.81ra35, 2011.

HOURANI, R.; KAKKAR, A. Advances in the elegance of chemistry in designing dendrimers. Macromol. Rapid Commun., v.31, p.947-974, 2010.

HOURANI, R.; SHARMA, A.; KAKKAR, A. Designing dendritic frameworks using versatile building blocks suitable for $\mathrm{Cu}$-catalyzed alkyne azide 'click' chemistry. Tetrahedron Lett., v.51, p.3792-3795, 2011.

HULT, A. Hyperbranched polymers. In: MARK, H.F. (Ed.). Encyclopedia of polymer science and technology. 2.ed. Hoboken: John Wiley \& Sons, 2003. p.722-743.

JANSEN, J.F.G.A.; DE BRABANDER VAN DEN BERG, E.M.M.; MEIJER, E.W. Encapsulation of guest molecules into a dendritic box. Science, v.266, p.1226-1229, 1994.

JANSEN, J.F.G.A.; MEIJER, E.W. The dendritic box: shapeselective liberation of encapsulated guests. J. Am. Chem. Soc., v.117, p.4417-4418, 1995.

KENSINGER, R.D.; CATALONE, B.J.; KREBS, F.C.; WIGDAHL, B.; SCHENGRUND, C.-L. Novel polysulfated galactose-derivatized dendrimers as binding antagonists of human immunodeficiency virus type 1 infection. Antimicrob. Agents Chemother., v.48, p.1614-1623, 2004b.

KENSINGER, R.D.; YOWLER, B.C.; BENESI, A.J.; SCHENGRUND, C.-L. Synthesis of novel, multivalent glycodendrimers as ligands for HIV-1 gp120. Bioconjugate Chem., v.15, p.349-358, 2004a. 
KOLHE, P.; MISRA, E.; KANNAN, R.M.; KANNAN, S.; LIEH-LAI, M. Drug complexation, in vitro release and cellular entry of dendrimers and hyperbranched polymers. Int. J. Pharm., v.259, p.143-160, 2003.

MILHEM, O.M.; MYLES, C.; MCKEOWN, N.B.; ATTWOOD, D.; D'EMANUELE, A. Polyamidoamine starburst dendrimers as solubility enhancers. Int. J. Pharm., v.197, p.239-241, 2000.

MORALES-SERNA, J.A.; BOUTUREIRA, O.; SERRA, A.; MATHEU, M.I.; DIAZ, Y.; CASTILLON, S. Synthesis of hyperbranched $\beta$-galceramide-containing dendritic polymers that bind HIV-1 rgp120. Eur. J. Org. Chem., v.14, p.2657-2660, 2010

MOUREY, T.H.; TURNER, S.R.; RUBENSTEIN, M.; FRÉCHET, J.M.J.; HAWKER, C.J.; WOOLEY, K.L. Unique behaviour of dendritic macromolecules: intrinsic viscosity of polyether dendrimers. Macromolecules, v.25, p.2401-2406, 1992.

NEIBERT, K.; GOSEIN, V.; SHARMA, A.; KHAN, M.; WHITEHEAD, M.A.; MAYSINGER, D.; KAKKAR, A. "Click" dendrimers as anti-inflammatory agents: with insights into their biding from molecular modeling studies. Mol. Pharmaceutics, v.10, p.2502-2508, 2013.

NEIRA, J.L. The capsid protein of human immunodeficiency virus: designing inhibitors of capsid assembly. FEBS J., v.276, p.6110-6117, 2009.

PEREZ-ANES, A.; STEFANIU, C.; MOOG, C.; MAJORAL, J.P.; BLANZAT, M.; TURRIN, C.-O.; CAMINADE, A.-M.; RICO-LATTES, I. Multivalent catanionic GalCer analogs derived from first generation dendrimeric phosphonic acids. Bioorg. Med. Chem., v.18, p.242-248, 2010.

PORTEVIN, D.; POUPOT, M.; ROLLAND, O.; TURRIN, C.O.; FOURNIÉ, J.J.; MAJORAL, J.P.; CAMINADE, A.M.; POUPOT, R. Regulatory activity of azabisphosphonatecapped dendrimers on human $\mathrm{CD} 4+\mathrm{T}$ cell proliferation enhances ex-vivo expansion of NK cells from PBMCs for immunotherapy. J. Transl. Med., v.7, p.82, 2009.

POUPOT, M.; GRIFFE, L.; MARCHAND, P.; MARAVAL, A.; ROLLAND, O.; MARTINET, L.; L'FAQIHI-OLIVE, F.E.; TURRIN, C.O.; CAMINADE, A.M.; FOURNIÉ, J.J.; MAJORAL, J.P.; POUPOT, R. Design of phosphorylated dendritic architectures to promote human monocyte activation. FASEB J., v.20, p.2339-2351, 2006.
RELE, S.M.; CUI, W.; WANG, L.; HOU, S.; BARR-ZARSE, G.; TATTON, D.; GNANOU, Y.; ESKO, J.D.; CHAIKOF, E.L. Dendrimer-like PEO glycopolymers exhibit antiinflammatory properties. J. Am. Chem. Soc., v.127, p.1013210133, 2005.

RUPP, R.; ROSENTHAL, S.L.; STANBERRY, L.R. VivaGel (SPL7013 Gel): a candidate dendrimer-microbicide for the prevention of HIV and HSV infection. Int. J. Nanomed., v. 2, p.561-566, 2007.

SCHLÜTER, A.D.; RABE, J.P. Dendronized polymers: synthesis, characterization, assembly at interfaces, and manipulation. Angew. Chem. (Int. Ed. Engl.), v.39, p.864883, 2000.

SHARMA, A.; KHATCHADOURIAN, A.; KHANNA, K.; SHARMA, R.; KAKKAR, A.; MAYSINGER, D. Multivalent niacin nanoconjugates for delivery to cytoplasmic lipid droplets. Biomaterials, v.32, p.14191429, 2011a.

SHARMA, A.; NEIBERT, K.; SHARMA, R.; HOURANI, R.; MAYSINGER, D.; KAKKAR, A. Facile construction of multifunctional nanocarriers using sequential click chemistry for applications in biology. Macromolecules, v.44, p.521-529, 2011 b.

SOLIMAN, G.M.; SHARMA, A.; MAYSINGER, D.; KAKKAR, A. Dendrimers and miktoarm polymers based multivalent nanocarriers for efficient and targeted drug delivery. Chem. Commun., v.47, p.9572-9587, 2011.

STICHT, J.; HUMBERT, M.; FINDLOW, S.; BODEM, J.; MÜLlER, B.; DIETRICH, U.; WERNER, J.; KR ÄUSSLICH, H.G. A peptide inhibitor of HIV-1 assembly in vitro. Nat. Struct. Mol. Biol., v.12, p.671-677, 2005.

TAKAYANAGI, H. Osteoimmunology: shared mechanisms and crosstalk between the immune and bone systems. Nat. Rev. Immunol., v.7, p.292-304, 2007.

TELWATTE, S.; MOORE, K.; JOHNSON, A.; TYSSEN, D.; STERJOVSKI, J.; ALDUNATE, M.; GORRY, P.R.; RAMSLAND, P.A.; LEWIS, G.R.; PAULL, J.R.; SONZA, S.; TACHEDJIAN, G. Virucidal activity of the dendrimer microbicide SPL7013 against HIV-1. Antiviral Res., v.90, p.195-199, 2011. 
TOMALIA, D.A.; DEWALD, J.; HALL, M.; MARTIN, S.; SMITH, P. Reprints of the 1st SPSJ International Polymer Conference. Soc. Polym. Sci., p.65, 1984.

TYSSEN, D.; HENDERSON, S.A.; JOHNSON, A.; STERJOVSKI, J.; MOORE, K.; LA, J.; ZANIN, M.; SONZA, S.; KARELLAS, P.; GIANNIS, M.P.; KRIPPNER, G.; WESSELINGH, S.; MCCARTHY, T.; GORRY, P.R.; RAMSLAND, P.A.; CONE, R.; PAULL, J.R.; LEWIS, G.R.; TACHEDJIAN, G. Structure activity relationship of dendrimer microbicides with dual action antiviral activity. PLoS One, v.5, p.e12309, 2010.
WIWATTANAPATAPEE, R.; JEE, R.D.; DUNCAN, R. PAMAM dendrimers as a potential oral drug delivery system: dendrimer complexes with piroxicam. Proc. Int. Symp. Control. Rel. Bioact. Mater., v.26, p.145-146, 1999. 